\title{
The viability of deep-frozen cow embryos
}

\author{
S. Willadsen, C. Polge and L. E. A. Rowson \\ A.R.C. Institute of Animal Physiology, Animal Research Station, \\ 307 Huntingdon Road, Cambridge CB3 OJQ, U.K.
}

\begin{abstract}
Summary. Day 7 cow embryos were frozen in $1.5 \mathrm{M}-\mathrm{DMSO}$ in PBS at $0.3^{\circ} \mathrm{C} / \mathrm{min}$ to $-36^{\circ} \mathrm{C}$ and at $0 \cdot 1^{\circ} \mathrm{C} / \mathrm{min}$ between -36 and $-60^{\circ} \mathrm{C}$ before being plunged directly into liquid nitrogen. They were subsequently thawed (rapidly to $-50^{\circ} \mathrm{C}$, at $4^{\circ} \mathrm{C} / \mathrm{min}$ from -50 to $-10^{\circ} \mathrm{C}$, and rapidly again) to room temperature. Embryonic viability was tested by four different transfer techniques. Maximum pregnancy rate $(8 / 12)$ was obtained with surgical transfer immediately after thawing and dilution of DMSO.
\end{abstract}

\section{Introduction}

Survival of cow embryos after storage at $-196^{\circ} \mathrm{C}$ was first reported by Wilmut \& Rowson (1973). The embryo stages which were deep-frozen were more advanced (Days 10-13 after oestrus) than the morulae-early blastocysts (Days 5-8) generally used for transplantation in cattle, and the viability of the frozen-thawed embryos was quite low. Subsequent attempts to deep-freeze Day 5 morulae and younger cow embryos gave almost completely negative results. Similar experiments with early blastocysts were relatively successful (Willadsen, Trounson, Polge, Rowson \& Newcomb, 1976), but the overall survival rate, in terms of the proportion of frozen-thawed early blastocysts developing normally after transplantation ( $33 \%$ ), was considerably below that generally obtained with fresh embryos $(60-80 \%)$. In the present paper the results obtained after transplantation of cow embryos, frozen and thawed by a modification of the original method, are reported.

\section{Materials and Methods}

Mature heifers of mixed breed were used as embryo donors and recipients. The general methods employed for induction of superovulation in donors, surgical collection and transplantation of embryos, and synchronization of oestrus in recipients were those described by Trounson, Willadsen \& Rowson (1976).

The embryos were collected from donors on Days $6 \frac{1}{2}-7 \frac{1}{2}$ after the onset of standing heat. Between collection and deep-freezing the embryos were stored at $\sim 20^{\circ} \mathrm{C}\left(18-22^{\circ} \mathrm{C}\right)$ in phosphate-buffered saline (PBS: Whittingham, 1971) for 3-6 h. Only very late morulae and early blastocysts were used.

The deep-freezing method was as follows. (1) Addition of $1.5 \mathrm{M}$-DMSO at $20^{\circ} \mathrm{C}$ in three steps $(0.5 \mathrm{M}$ for $10 \mathrm{~min}, 1.0 \mathrm{M}$ for $10 \mathrm{~min}, 1.5 \mathrm{M}$ for $30-40 \mathrm{~min}$ ). After $15 \mathrm{~min}$ in $1.5 \mathrm{M}$-DMSO in PBS the embryos were pipetted into ampoules, drawn from $0.5 \times 5 \mathrm{~cm}$ test-tubes, containing $0.25 \mathrm{ml} 1.5$ M-DMSO in PBS. The ampoules, each containing 2-5 embryos, were sealed over a gas flame. (2) Cooling at $1{ }^{\circ} \mathrm{C} / \mathrm{min}$ from $\sim 20^{\circ} \mathrm{C}$ to -6 to $-7^{\circ} \mathrm{C}$. (3) Induction of crystallization of the freezing medium by local cooling of the wall of the ampoule with a pair of forceps cooled in liquid nitrogen. (4) Freezing from $-7^{\circ} \mathrm{C}$ to -35 to $-36^{\circ} \mathrm{C}$ at $0.3^{\circ} \mathrm{C} / \mathrm{min}$, then to $-60^{\circ} \mathrm{C}$ at $0.1{ }^{\circ} \mathrm{C} / \mathrm{min}$. From $-60^{\circ} \mathrm{C}$ the ampoules were plunged directly into liquid nitrogen. (5) After periods of $1 \frac{1}{2}-3$ months in liquid nitrogen the ampoules were transferred to an ethanol bath at $-50^{\circ} \mathrm{C}$ and thawed at $4^{\circ} \mathrm{C} / \mathrm{min}$ to $-10^{\circ} \mathrm{C}$. From $-10^{\circ} \mathrm{C}$ the ampoules were rewarmed rapidly in water at $\sim 20^{\circ} \mathrm{C}$. (6) Immediately after rewarming to $\sim 20^{\circ} \mathrm{C}$ the embryos were transferred to freshly prepared $1.5 \mathrm{M}$-DMSO in PBS, and the cryoprotectant was removed in six steps (1.5 M-DMSO for $5 \mathrm{~min}, 1.25 \mathrm{M}, 1.0 \mathrm{M}, 0.75 \mathrm{M}, 0.5 \mathrm{M}$ and $0.25 \mathrm{M}$ for $10 \mathrm{~min}$ each, PBS). 
The morphology of the embryos, including the state of the zona pellucida, was assessed. Only embryos which were morphologically indistinguishable from unfrozen embryos were subsequently used for transplantation; the others were cultured for $20-24 \mathrm{~h}$ at $37^{\circ} \mathrm{C}$ in $1 \times 5 \mathrm{~cm}$ test-tubes containing 2-2.5 ml PBS + sheep serum, 4:1 (v/v).

Three transplantation experiments were carried out. In Exp. 1A, 11 embryos were transferred surgically to 10 recipients within $2 \mathrm{~h}$ of thawing and removal of DMSO. In Exp. 1B, 5 embryos were transferred surgically to 5 recipients after being kept for $12 \mathrm{~h}$ in PBS at $\sim 20^{\circ} \mathrm{C}$ following removal of DMSO. In Exp. 2, 10 embryos were transferred non-surgically to 10 recipients within $2 \mathrm{~h}$ of thawing and removal of DMSO with the aid of an insemination catheter (Cassou). In Exp. 3, 20 embryos were transferred 10 min-1 $\mathrm{h}$ after thawing without removal of DMSO. One embryo was transferred in $0.1 \mathrm{ml} 1.5 \mathrm{M}$-DMSO in PBS to each uterine horn of 10 recipients.

\section{Results and Discussion}

The results of Exps 1-3 are presented in Table 1. The deep-freezing method used in these experiments was chosen on the basis of results of similar experiments with sheep embryos (Willadsen, 1977). Earlier work had indicated that optimal freezing and thawing conditions were the same for cattle and sheep embryos once the early blastocyst stage was reached (Willadsen et al., 1976). This generalization was found to hold in the present experiments, in which the overall survival rate, as judged by morphological criteria after thawing, was about $80 \%$. About $30 \%$ of the frozen-thawed embryos had damaged zonae pellucidae, and a few were completely denuded. However, damage to the zona pellucida did not seem to be related to, or to affect, survival of the embryo itself, or to preclude normal embryonic development after transplantation. In Exp. 1A, 3 of 4 embryos which had cracked zonae pellucidae and 5 of 7 with intact zonae developed normally. The ultimate survival rate obtained in this experiment is the highest so far reported for frozen-thawed cow embryos and probably higher than any recorded previously for deep-frozen mammalian embryos. The latter is a reflection of the level of efficiency which may be attained with surgical embryo transplantation in cattle. Similarly, the pregnancy rates obtained in Exp. 2 reflect the inadequacy, at least for Day $6 \frac{1}{2}-7 \frac{1}{2}$ embryos, of the particular non-surgical transfer technique employed (see Newcomb \& Rowson, 1976).

Widespread use of embryo transplantation in cattle breeding awaits not only the development of an efficient method for non-surgical transfer, but probably also a simpler and less laborious deepfreezing technique. In the context of surgical transplantation, alterations of the present method do not seem to be urgently required. The results of Exp. 3 indicate that removal of DMSO from the medium before transplantation is essential for continued embryonic development. If embryos frozen and thawed by the present technique are placed in PBS directly after thawing, the blasto-

Table 1. The results of transfer of cow embryos after deep-freezing

\begin{tabular}{|c|c|c|c|c|}
\hline & \multicolumn{2}{|c|}{ Exp. 1} & Exp. 2 & \multirow{2}{*}{ 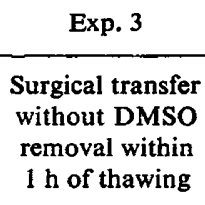 } \\
\hline & $\begin{array}{l}\text { (A) Surgical transfer } \\
\text { within } 2 \mathrm{~h} \text { of } \\
\text { DMSO removal }\end{array}$ & $\begin{array}{c}\text { (B) Surgical transfer } \\
12 \mathrm{~h} \text { after DMSO } \\
\text { removal }\end{array}$ & $\begin{array}{c}\text { Non-surgical } \\
\text { transfer within } 2 \mathrm{~h} \\
\text { of DMSO removal }\end{array}$ & \\
\hline \multicolumn{5}{|l|}{ Embryos } \\
\hline No. frozen & 12 & 8 & 17 & 22 \\
\hline No. surviving & 12 & 6 & 11 & 20 \\
\hline No. transferred & 11 & 5 & 10 & 20 \\
\hline normally & 8 & 2 & 3 & 1 \\
\hline \multicolumn{5}{|l|}{ Recipients } \\
\hline No. & 10 & 5 & 10 & 10 \\
\hline No. pregnant & 7 & 2 & 3 & 1 \\
\hline
\end{tabular}


meres swell and disintegrate (S. Willadsen, unpublished observation). The same phenomenon was probably the cause of the low pregnancy rate in the present experiment. Other ways of removing or diluting DMSO could be devised, and experiments with sheep embryos suggest that any part of the present deep-freezing method can be altered without too much effect (Willadsen, 1977). The nature and direction of such alterations must be governed by the conditions under which the method is to be applied and in particular by the transfer method and its instrumentation. However, it would seem that the present deep-freezing method adequately fulfils the more basic requirements for a method of long-term storage and long-distance transport of cattle embryos.

We thank other members of the staff for skilled assistance. Financial support from the Milk Marketing Board of England and Wales and the Commission of the European Communities is also gratefully acknowledged.

\section{References}

Newcomb, R. \& Rowson, L.E.A. (1976) Aspects of the non-surgical transfer of bovine eggs. Proc. $8 \mathrm{th}$ Int. Congr. Anim. Reprod. \& A.I., Krakow, Vol. III, pp. 262-265.

Trounson, A.O., Willadsen, S.M. \& Rowson, L.E.A. (1976) The influence of in-vitro culture and cooling on the survival and development of cow embryos. J. Reprod. Fert. 47, 367-370.

Whittingham, D.G. (1971) Survival of mouse embryos after freezing and thawing. Nature, Lond. 233, 125126.

WILLADSEN, S.M. (1977) Factors affecting the survival of sheep embryos during deep-freezing and thawing. In The Freezing of Mammalian Embryos (Ciba Found. Symposium.), pp. 175-189. ElsevierExcerpta Medica, Amsterdam.

Willadsen, S.M., Trounson, A.O., Polge, C, Rowson, L.E.A. \& Newcomb, R. (1976) Low temperature preservation of cow eggs. In Egg Transfer in Cattle, pp. 117-124. Ed. L.E.A. Rowson. Commission of the European Communities, Luxembourg.

WiLmut, I. \& Rowson, L.E.A. (1973) Experiments on the low temperature preservation of cow embryos. Vet. Rec. 92, 686-690.

Received 14 July 1977 